\title{
Uma revisão crítica da antropologia de Carmen Junqueira
}

\section{LINDINALVA LAURINDO TEODORESCU}

Este artigo $^{1}$ tem como finalidade uma revisão crítica da antropologia produzida por Carmen Junqueira, ao longo de cinquenta anos de pesquisa junto a populações indígenas.

Segundo a antropóloga Alcida Rita Ramos (2010), por razões históricas, a antropologia indígena representa o carro chefe da antropologia nacional, reconhecida no Brasil e no exterior. Para ela, embora seja estudada por uma minoria de etnólogos nos departamentos de antropologia do país, a disciplina ocupa um espaço importante no imaginário profissional.

Carmen Junqueira faz parte dessa minoria que, ao longo de décadas registrou as mudanças ocorridas nas sociedades indígenas, relatou o papel dos mitos e ritos na composição do universo Kamaiurá e Cinta Larga e se engajou na luta para preservar os direitos fundamentais destes povos.

$\mathrm{Na}$ esteira dos antropólogos que firmaram as raízes da antropologia indígena brasileira, como Eduardo Galvão, Darcy Ribeiro e Carlos Moreira Neto, Carmen Junqueira compõe uma geração que instaurou uma forma de produzir antropologia no Brasil, privilegiando a pesquisa empírica de longa permanência no campo. Elegeu o povo Kamaiurá, no alto $\mathrm{Xingu}^{2}$, para estudar em profundidade e dedicou-se depois aos Cinta Larga no Parque Indígena Aripuanã, no Mato Grosso 3 .

Em seus primeiros escritos, ainda na década de 1960, Carmen Junqueira focou seu interesse nas formas de produção e distribuição de bens na sociedade Kamaiurá. Ao longo dos anos, voltou sua atenção para as transformações ocorridas na história dos povos indígenas, tanto nas condições de existência quanto nas interpretações de mundo a elas associadas.

Diante da extensa produção de Carmen Junqueira, foram selecionados para análise apenas as publicações referentes ao povo Kamaiurá, tendo em conta sua longa relação com este grupo. Dos tra-

1 Agradeço a Rinaldo Sérgio Vieira Arruda pela leitura criteriosa deste texto e por suas críticas pertinentes e a Paulo Roberto Teixeira pela releitura atenta e por suas observaçóes oportunas.

2 Compõem os povos do alto Xingu, os Kamaiurá, Aweti, Waurá, Mehinaco, Iawalapati, Kuikuro, Kalapalo e Nahukwa. Estes povos que ocuparam a região dos formadores do rio Xingu, são procedentes de grupos com tradições culturais diversas que passaram a compartilhar um mesmo habitat cultural. São eles: os Karib, Tupi, Aruak, Jê e Trumai.

3 As pesquisas junto ao povo Kamaiurá se concentram no período de 1965 a 1979 e de 1993 a 2006. Na sociedade Cinta Larga a pesquisa foi realizada de 1979 a 1986. 
balhos, foram retidos quatro temas que, além de recorrentes em suas pesquisas, parecem constituir o cerne de sua antropologia. São eles: a composição do universo Kamaiurá, o espaço das mulheres nas sociedades indígenas, o imaginário e o simbólico na configuração do tempo Kamaiurá e o mundo animal e o mundo humano ou a relação natureza e cultura ${ }^{4}$. Neste último item, foi feita uma tentativa de comparação entre a antropologia de Carmen Junqueira e outras perspectivas que dão conta da composição do universo indígena, em termos de pluralidade de mundos, principalmente os modelos desenvolvidos por Philippe Descola (2005; 2017) e Viveiros de Castro (2002), mas também a sociologia política de Luc Boltanski et Laurent Thévenot (1991) . Ao relacionar as análises de Carmen Junqueira com novas problemáticas da antropologia contemporânea, buscou-se mostrar o alcance e a relevância de sua obra, em um debate produtivo da antropologia clássica.

Uma das premissas da antropologia de Carmen Junqueira é a necessidade de dar um tratamento histórico aos dados colhidos. Processos históricos e contexto de pesquisa são considerados fundamentais para a interpretação de um evento social. Reivindicando, antes de tudo, sua condição de etnóloga de campo, Carmen Junqueira, reiteradamente, alerta para a tentação do antropólogo falar em nome do índio para explicar a visão de mundo desses povos ancestrais ou do risco de se reduzir a complexidade das sociedades indígenas a modelos teóricos, por vezes pouco flexíveis, o que fecha as possibilidades de ampliar os horizontes da compreensão interétnica e da complexidade da realidade estudada.

A duração da pesquisa e a permanência do etnólogo no campo são elementos fundamentais para o entendimento das implicações sociais das diferentes etapas de uma atividade econômica ou dos múltiplos ritos que celebram a cosmologia e as tradições e que compõem um sistema social bastante ordenado por etiquetas, regras e valores morais. É preciso ter paciência e sorte para ter acesso a essa dimensão da realidade social, diz a etnóloga.

\section{A Composição do Universo Kamaiurá}

\section{As formas de produção, parentesco e relações de poder}

Em suas primeiras pesquisas junto ao povo Kamaiurá, na década de 1960 (Junqueira: 1967; 1978), Carmen Junqueira procurou entender como se dava a organização social desta sociedade, focando suas análises na relação entre economia, parentesco e sustentação de poder. Neste período, sua proximidade com as teorias marxistas a levou a confrontar a economia política e a economia dos povos Kamaiurá, mostrando que a produtividade e a troca não obedeciam aos princípios da economia de mercado. Baseou-se em conceitos do materialismo histórico, como forças produtivas e relações de

4 Para discorrer sobre estes temas foram selecionadas as seguintes publicações: Tese de doutorado: Os Kamaiura e o Parque Nacional do Xingu 1967; os livros: os Índios de Ipavu - um estudo sobre a vida do grupo Kaiamurá 1978; Sexo e Desigualdade entre os Kamaiurá e os Cinta Larga 2002; Antropologia indígena: Uma nova introdução 2008; O tempo e o imaginário - O pajé e a antropóloga, 50 anos de diálogo 2017 e os artigos: Pajés e feiticeiros 2004; Linguagem dos Ritos 2014.

5 Embora com foco de pesquisa diferente e a elaboração de conceitos que conduzem a modelos próprios, a perspectiva em termos de pluralidade de mundos encontra expressão também nos trabalhos de Bruno Latour, François Dosse, entre outros. No Brasil, além de Eduardo Viveiros de Castro, que desenvolveu a teoria do perspectivismo, o pluralismo de mundo encontra ressonância, entre outros, no trabalho de Manuela Carneiro da Cunha. 
produção, para dar conta das complexas relações de hierarquia e poder que se articulam ao processo produtivo, nessa sociedade.

A partir dessas análises, Junqueira procurou mostrar o importante papel social da atividade econômica na sociedade Kamaiurá e como essa atividade contribui para o estreitamento de laços entre os membros de um mesmo grupo e entre os diferentes grupos, através, principalmente, de alianças matrimoniais, mas também de cerimonias como o Moitará e o Kuarup que, sob forma de rito, sustentam uma boa parte da economia do grupo.

O controle social do grupo, que garante o seu equilíbrio, é assegurado pelo cumprimento dos deveres definidos pelas relações de parentesco ${ }^{6}$. Estas, por sua vez, são em boa parte determinadas por motivações políticas legitimadas pelos membros da comunidade, principalmente os idosos ou de maior prestígio social. Da relação intrínseca entre parentesco e poder econômico se definem os componentes das unidades de produção, no âmbito da cooperação entre diferentes chefes das casas.

Para a etnóloga, a explicação para a expectativa em torno da instituição casamento que se observa na cultura Kamaiurá, além da função de procriação e de natureza sexual, deve ser buscada na esfera econômica, decorrente da divisão sexual do trabalho ${ }^{7}$. $\mathrm{O}$ fato mesmo do homem poder realizar vários casamentos lhe permite aumentar a prole e, consequentemente, aumentar a força de trabalho, o que lhe confere prestígio e poder.

As relações de parentesco são, ao mesmo tempo, formas de expressão das relações de produção e de alianças políticas. É a partir delas que se estabelecem as modalidades de reciprocidade, de obrigação e de direitos. A distribuição é uma etapa fundamental desse processo e vai ser entendida como uma ação de reciprocidade. O compromisso mútuo de cumprir obrigações culturais e a garantia de novas trocas ultrapassam as relações econômicas e contribui para o estreitamento de laços com outros grupos.

\section{A generosidade ostentada e o sacrifício do líder}

$\mathrm{Na}$ sociedade Kamaiurá, a participação no processo produtivo não determina a posição social de cada indivíduo e o produto, que é um bem socialmente distribuído, não cria distinção social significativa. Ao contrário das sociedades capitalistas, a participação no processo produtivo iguala os indivíduos. O poder do líder não se define pela acumulação de riqueza, mas por seu prestígio pessoal, que está essencialmente ligado a sua generosidade. Isto quer dizer que no grupo, a competição para maior prestígio se dá na esfera da distribuição e não na esfera da produção.

A disputa política pelos postos de liderança e de maior prestígio é um dado que se destaca nas análises de Carmen Junqueira. No texto Pajés e feiticeiros (2004), a etnóloga aprofunda esse tema que, segundo ela, define a vida da aldeia, o que atesta sua importância no equilíbrio da ordem social, mostrando como as disputas políticas pelos postos de maior prestígio alimentam um fluxo constante

60 casamento preferencial ideal se dá entre primos cruzados, mas as alianças com outras casas (outras famílias do mesmo grupo) são realizadas com frequência. O núcleo permanente tende a ser a formação patrilocal (por regra de residência), composta por diversas famílias nucleares vivendo sob uma mesma casa. Sob a liderança do dono da casa, todos participam das tarefas ligadas à produção de alimentos.

$7 \mathrm{Na}$ divisão de trabalho, as mulheres se ocupam dos filhos, dos afazeres domésticos, plantio e colheita na roça e preparação dos alimentos. Ao homem cabe a pesca, a caça e a limpeza da roça. 
de intrigas que atingem líderes de facções rivais, com o objetivo de minar pretensões políticas ou enfraquecer o poder dos adversários.

Tornar-se líder exige disciplina. E manter-se líder demanda dar prova de habilidade política. A autoridade do líder depende de seu prestígio, o que requer um desprendimento sem limites de seus bens. Segundo Carmen Junqueira, ainda que o chefe ostente com orgulho a sua generosidade, a obrigatoriedade de redistribuir tudo que é produzido ou adquirido não se concretiza sem o constrangimento de perceber que a situação o obriga a trabalhar mais, para atender os pedidos dos parentes e demais Kamaiurá. Assim procedendo, entretanto, o líder firma sua grandeza frente ao grupo e alimenta a dependência daqueles que recebem seus favores. Esta prática social Carmen Junqueira define como forma de "sustentáculo de poder", já que possibilita o aumento de prestígio do chefe e torna devedores os membros do grupo (Junqueira 1978; 2004). As análises deixam claro que o ato de generosidade que sustenta a posição do líder exige sacrifício e renúncia. Para dar prova de sua grandeza, o líder deve constantemente mostrar desinteresse por seus bens. A liderança é assim posta à prova a todo instante.

O exemplo não poderia ser mais ilustrativo do modelo de justiça defendido por Boltanski e Thévenot (1991), para dar conta das situações de disputa. Neste modelo, a organização em torno do líder, do chefe ou do rei, diz respeito a um mundo tradicional e ordenado nas fronteiras do que os autores nomeiam cité domestique ${ }^{8}$, onde a personalidade dos grandes é aquela de um servidor, que se sacrifica em nome dos pequenos. Os estados de grandeza não podem ser duravelmente atribuídos às pessoas e supõem-se que sejam periodicamente verificados e retribuídos a fim que seja mantida para cada um, a possiblidade de ocupar todos os estados.

$\mathrm{O}$ fato das grandezas não serem rigidamente vinculadas às pessoas favorece os litígios, quer dizer os desacordos entre as pessoas. A noção mesma de prova a que cada um tem que se submeter para sustentar seu prestígio indica que, numa disputa, a saída é incerta e é preciso um dispositivo particularmente consistente para pôr fim à situação de conflito.

O sistema de retribuição e a noção de generosidade, largamente valorizada pelos Kamaiurá, constituem sem dúvida um dispositivo capaz de frear toda tentativa de reverter a liderança do chefe da aldeia. A organização política dos Kamaiurá é relativamente simples e fundada em poder não coercitivo, em razão mesmo de não perceber contradições básicas nas formas de organização social. Segundo Carmen Junqueira, a ausência de poder coercitivo pode obscurecer a especificidade do fato político.

A disputa pelo poder na sociedade Kamaiurá faz emergir na aldeia suspeitas e acusações que atingem os líderes de outros grupos. As práticas colocadas em ação para alcançar ou se manter no poder são, segundo Junqueira, "recursos auxiliares neutralizadores do prestígio alheio". Um exemplo, diz dela, são as ofensas proferidas para depreciar os adversários. Se as ofensas podem ser resolvidas nas lutas $\mathrm{Hu}$ ka-Huka onde cada um, em sistema de equivalência, vai afirmar sua legitimidade, ofensas mais graves, como a acusação de feitiçaria, podem levar ao ostracismo ou à morte (Junqueira 2002).

Nesses casos a situação se complica porque os índios lançam mão de dispositivos que fogem a todo princípio de equivalência que define uma cité, ou seja, um mundo comum, no modelo de justiça.

8 A noção de cité aqui é entendida como pólis grega e está associada à noção de direitos e deveres que cada um deve cumprir para o bem geral de todos. As outras cités do modelo são: inspiração, renome, industrial e cívica. 
Em um tal contexto de disputa, diz Carmen Junqueira, "Os índios se empenham em arranjos de poder, lançando mão de mecanismos sofisticados de ação política que envolvem não apenas o mundo dos homens, como dos espíritos.... Sem qualquer sinal que demarque a passagem de um para o outro desses mundos, trava-se na aldeia uma disputa velada e incessante, para neutralizar a ação de opositores e ampliar espaços de controle”. Numa tal situação, prossegue ela, "a fronteira entre o mundo dos homens e o mundo dos espíritos parece não existir" (Junqueira 2002: 36). Cabe aos pajés resolver a situação, desfazendo o feitiço, o que não deixa de ser um desafio dos poderes da natureza.

De acordo com o modelo de Boltansky e Thévenot, um dos preceitos básicos para se resolver uma situação de disputa é garantir a equivalência entre as partes, com base na argumentação fundamentada em um dos princípios de justiça (ou cité). Na ausência de equivalência, a argumentação se torna ineficaz e ocorre um deslocamento de um regime ordenado, segundo um princípio de justiça, para um regime de violência ${ }^{9}$. As análises de Carmen Junqueira dão razão à essa premissa, quando questionam se é real a existência do feiticeiro ou se aquilo que o etnólogo presencia são somente crises de disputa política acirrada, numa sociedade que não conta com uma área bem articulada que torne legítimo e explícito o duelo de palavras entre opositores. Na falta desse espaço, a morte, que é a maior violência que o ser humano pode experimentar, instaura ela mesma uma escalada interminável de violência (Junqueira 2004).

\section{Mudanças e interação grupal entre os povos do alto Xingu}

Em seu livro "Os Índios de Ipavu” (1978), Junqueira retoma sua tese de 1967 sobre as mudanças ocorridas entre os povos do alto Xingu, com foco nos Kamaiurá, e faz uma revisão crítica de sua abordagem na época, então sustentada na noção de sistemas evolutivos.

Em suas primeiras pesquisas entendeu que as relações básicas no processo de produção do grupo não foram inicialmente afetadas de maneira substancial. Embora dependendo do sistema econômico nacional, os Kamaiurá não tinham sido envolvidos diretamente na formação de produção capitalista, em razão da presença protecionista da direção do Parque Nacional do Xingu (atual Parque Indígena do Xingu) e do relativo isolamento da área.

Concluiu que, ao mesmo tempo em que a interação grupal dos vários povos xinguanos propiciava difusão cultural e a consequente uniformidade de estilo de vida, estimulava a permanência de alguns elementos que passavam a desempenhar a função de mecanismos adaptativos. O equilíbrio adaptativo do grupo residia em parte na preservação dos artesanatos de cada grupo, o que implicava pouca integração de outras especialidades ${ }^{10}$. No final da década de 1970 essa explicação não correspondia aos avanços de suas pesquisas. Na verdade, reconhece a etnóloga, a abordagem em termos de sistema adaptativo

9 O modelo de Boltanski e Thévenot abre a possibilidade de tratar com seres da ordem divina ou sobrenatural, onde se encontram os espíritos, na cité da inspiração. Mas o modelo não permite levar provas de uma cité para outra, para pôr fim a uma disputa.

10 Os artesanatos especializados são o arco preto, produção dos Kamaiurá, os colares de lâminas de concha dos Kuikuro; as panelas de cerâmicas dos Waurá e os o cinto de discos de caramujo dos Kalapalo. 
se apoiava em uma perspectiva evolucionista ${ }^{11}$ e pretendia sugerir uma possível causa da preservação das especializações.

Ao aprofundar suas pesquisas Carmen Junqueira se deu conta que o equilíbrio adaptativo como explicação da uniformidade cultural deixava de considerar a dramática realidade em que viviam o povo Trumai e os demais povos xinguanos já relatada desde o final do século XIX ${ }^{12}$. Além disso, não levava em conta que bens e serviços são valores que circulam independente dos vínculos de amizade e de hostilidade que possam existir. Os grupos desenvolvem atividades intermediárias de troca e neste movimento estabelecem redes de relações sociais que congregam as diferentes atividades culturais em um sistema mais amplo. As cerimônias religiosas e desportivas, por exemplo, estabelecem a presença imperativa de outros grupos. A uniformidade cultural é consequência desses contatos e não se restringem à esfera mercantil.

\section{Política protecionista e deslocamento de poder na aldeia de Ipavu}

Nas pesquisas dos anos 1970, a identificação das mudanças decorrentes dos diferentes contatos (funcionários, pesquisadores, não índios) passou a ser o ponto básico para a compreensão das relações no alto Xingu. Notava Carmen Junqueira que a política protecionista praticada pelo posto ${ }^{13}$ gerava desestabilização da organização social, na medida que produzia modificações importantes nas configurações culturais dos grupos e na sua estrutura social. Isto implicava desaparecimento gradativo das unidades de produção e sua dissociação das unidades de consumo.

A introdução de novos instrumentos de trabalho, como arma de fogo e facão, gerava crescente dependência econômica dos índios em relação ao posto. Além disso, recebiam o que necessitavam e não eram estimulados a retribuir com outros produtos. A retribuição se dava através da subordinação ao posto, que ditava as regras, desde proibições absolutas, como as relações sexuais entre índios e não índios, até o aconselhamento (Junqueira 1978: 79, 80). Junqueira notou um deslocamento do foco de poder dos índios para o posto. Os líderes nativos perdiam parte da capacidade de decisão. As questões de maior importância para a vida econômica e política da aldeia eram decididas fora do grupo. Do mesmo modo a existência de médicos profissionais do posto reduzia os poderes curativos do pajé.

Reconhecia, contudo, que o modelo protecionista, apesar de seu caráter assistencial, funcionava como um mecanismo atenuador e retardador do processo de mudança. O líder da aldeia guardava relativa autonomia na medida em que o posto procurava não intervir em assuntos nativos, ainda que o seu poder de decisão diminuísse. A continuação da existência do líder implicava uma certa hierarquia res-

11 A noção de sistema adaptativo tem origem no modelo do processo civilizatório desenvolvido por Darcy Ribeiro, 1968, e teve forte influência nas ciências sociais, na década 1970. Mais tarde este modelo foi bastante criticado por suas características evolucionistas, sem considerar sua imensa contribuição para o entendimento do complexo processo de desenvolvimento da sociedade brasileira, que nunca perdeu sua força. Em 1995, Darcy Ribeiro atualizou e completou suas análises com a publicação de sua obra, O povo brasileiro.

12 Os relatos foram produzidos principalmente pelo antropólogo Buell Quain, em 1955, e pelo pesquisador Karl Von Den Steinen, em 1940. Ver ainda Junqueira (2017), sobre os primeiros relatos feitos por diferentes estudiosos no século XIX.

13 O Parque Indígena do Xingu dispõe de dois postos: o Posto Leonardo Villas Boas se ocupa dos índios Kalapalo, Kuikuro, Nahukwá, Matipuhy, Waurá, Mehinako, Jawalapiti, Kamaiurá, Aweti e Txicão e o Posto Diawarum se ocupa dos índios Trumai, Suyá, Juruna, Txucahamãe. Os trabalhos de Carmen Junqueira se referem ao Posto Leonardo Villas Boas. 
guardada e apontava que a dependência em relação ao posto não havia desorganizado toda a estrutura social do grupo, ainda que o processo de mudança de qualquer forma tivesse continuidade.

No final dos anos 1970, Junqueira já percebia um início de enfraquecimento do posto como centro de poder. Os índios já não aceitavam a mediação da direção do posto quando pretendiam realizar suas trocas. Além de argumentarem as vantagens de oferecer seus produtos na cidade, reivindicavam que somente os Kamaiurá e os parceiros da troca poderiam decidir as modalidades de transações. A partir destas análises, Carmen Junqueira expõe em seu livro "Os índios de Ipavu" (1978), os temas que doravante comporiam a base de suas reflexões, cujo foco principal seria mostrar como as noções de mito e rito, entendidos como símbolos de uma realidade social, contribuiriam para manter a visão de mundo dos povos indígenas e assim garantir maior integridade cultural.

\section{Os ritos como fundamento do sistema social}

A cerimônia do Kuarup, a luta Jawari e o sistema de troca Moitará são instituições intertribais que formam o alicerce de sustentação do sistema social dos grupos alto xinguanos. Partindo da ideia de que esses povos enfatizam nas cerimônias Kuarup, Jawari e Moitará tipos de relações ideais, Carmen Junqueira sustenta que estas cerimônias sintetizam as atitudes e comportamentos individuais e o intenso convívio intergrupal do alto Xingu.

A cerimônia do Kuarup aparece em diferentes momentos da pesquisa e em diferentes textos da antropóloga. Esta instituição, incontornável para se entender o universo Kamaiurá, comemora os mortos e remete à vivencia ritual do mito da criação. É assim, segundo Junqueira, uma rememoração desses dois atos ancestrais realizados pelo criador Mavutsinin ${ }^{14}$. Para além desta compreensão, diz a etnóloga, o Kuarup age também como incrementador da produção, porque sua preparação envolve três níveis da economia do grupo: a dos parentes mais próximos, a dos moradores da casa do morto (grupo doméstico) e a dos membros da aldeia. Os parentes próximos produzem os adornos, o grupo doméstico se encarrega dos alimentos que serão consumidos (armazenamento de bolos de mandioca e polvilho), os membros da aldeia colaboram com a pesca que será distribuída aos convidados, no final da cerimônia. Além de agir na incrementação da produção, o Kuarup expressa também a criação e a manutenção de vínculos sociais. A cerimônia contribui para o fortalecimento das relações entre as famílias da comunidade e entre os diferentes povos alto xinguanos.

A celebração do Kuarup é analisada como a expressão de um estado ideal de solidariedade. Carmen Junqueira considera a solidariedade como estratégia social inevitável, visando um grau de sociabilidade capaz de produzir o bem-estar de toda a sociedade.

Este estado ideal de solidariedade, consagrado na cerimônia do Kuarup, vai ser confrontado com a luta do Jawari. Esta cerimônia, segundo Junqueira, fará deslocar a relação de solidariedade para a de competição e afirmação da identidade do grupo. Com o propósito de vencer a competição e assegurar o prestígio, cada grupo vai se unir contra os demais participantes e assim firmar sua identidade grupal (Junqueira 2015: 23). 
A festa do Jawari envolve duas aldeias onde os protagonistas da luta devem atirar dardos um no outro, lançados com ajuda de um propulsor. Enquanto o Kuarup acontece todos os anos, a cerimonia do Jawari ocorre a cada dois anos, só podendo ser realizada depois que o morto, então homenageado, já o tenha sido pela cerimonia do Kuarup ${ }^{15}$. Tida como a festa de homenagem ao guerreiro, o Jawari indica também o momento de esquecer os mortos e voltar a ser feliz, como mostra Diego Faust Ramos (2010).

Ao confrontar as duas cerimônias, de um lado o ritual de solidariedade expresso no Kuarup, de outro a manifestação de hostilidade, socialmente aprovada, na luta do Jawari, Carmen Junqueira corrobora a tese defendida por Eduardo Galvão, quem em 1950 identificou no Jawari um mecanismo estabilizador das relações intertribais.

Outro elemento importante de afirmação da identidade do grupo é a cerimônia do Moitará, ocasião reservada às trocas entre índios do mesmo grupo e também com os outros povos indígenas. Carmen Junqueira reconhece que a troca de bens já não tem o mesmo papel de antes, mas mantém ainda sua importância reafirmada na cerimônia do Moitará. A etnóloga busca sustentação em Marshall Sahlins (1965) para conceber o Moitará como forma de intensificar as relações sociais entre aldeias, já que se espera que as trocas sejam realizadas dentro do que Sahlins chama de reciprocidade equilibrada ${ }^{16}$.

O Moitará persiste assim como instituição proporcionadora de contatos grupais e como oportunidade para que haja o confronto e a autoafirmação dos grupos como entidades distintas. A autoafirmação se materializa através da especialização manufatureira dos diferentes grupos. Especialização que propicia a necessidade de troca. O Moitará seria um mercado, cuja função é manter a integração de grupos distintos. A circulação de bens ultrapassa as relações econômicas e só pode ser entendida pela compreensão de suas articulações com as demais esferas da vida social.

No artigo "Linguagem dos ritos" (2015), Carmen Junqueira retoma o tema do Kuarup. Desta vez se debruçou sobre o conjunto de rituais que ocorrem quando do falecimento de um membro da comunidade, que culminam com a realização da cerimônia, marcando o fim do luto.

Neste artigo são apresentados os ritos fúnebres dos quais participam a família enlutada e os moradores da aldeia. Ritos eles mesmos ditados pelo movimento do sol, pelas etapas da lua, pelo surgimento das plêiades e das estações secas e chuvosas. A sequência de atos que compõem os ritos revela a reciprocidade na prestação de trabalho, favores e oferta de bens. Junqueira se detém na prática coletiva da pescaria. Entende que a reciprocidade envolvida na realização da cerimônia independe de simpatias ou antipatias, todo o grupo participa da pescaria. A tarefa é executada de acordo com um rígido protocolo que permite ampliar a colaboração. Deixar de participar de qualquer uma dessas obrigações implica em rompimento do vínculo social e, provavelmente em outros tempos, poderia levar ao acúmulo de tensão, diz a etnóloga.

15 Esta defasagem na realização das duas cerimonias tem por única finalidade impedir que aconteçam no mesmo ano, por razões de capacidade de produção dos alimentos a serem distribuídos nos dois momentos. (D. C. Ramos 2010; E. Galvão 1979).

16 A noção de reciprocidade definida por Sahlins (1965) obedece a uma tipologia que tem em um polo a solidariedade extrema, entendida como reciprocidade generalizada que não implica obrigação de recompensa. Em um ponto médio está a reciprocidade equilibrada que diz respeito ao intercambio no qual os termos são equivalentes, mas mais impessoal que a solidariedade extrema. No polo oposto situa-se a reciprocidade negativa, a forma mais impessoal das três e onde os interesses das partes são opostos e cada uma procura maior vantagem. (Junqueira 1967: 53; 1978: 27, 70). 
$\mathrm{Na}$ sequência de ritos que se realizam para atingir a cerimônia do Kuarup, Carmen Junqueira percebe a forma acabada do conceito de "fato social total", concebido por Marcel Mauss, no sentido de que este ritual materializa em um só ato e ao mesmo tempo as principais instituições que dão sustentação à estrutura do sistema social Kamaiurá. São elas: religiosas, econômicas, estéticas e político - familiais, estas últimas entendidas por Mauss como instituições morais. Essas instituições, que fundamentam a sociedade Kamaiurá, se apresentam nas cerimônias em formas particulares de produção e de consumo, revestidas de prestação, de distribuição e de elementos estéticos. Carmen Junqueira retoma as palavras de Mauss quando afirma que a circulação de bens e gentilezas, que sempre pressupõe a reciprocidade, é apenas um termo de um contrato muito mais geral e muito mais permanente. A aparência voluntária, diz Mauss, é menos o produto da generosidade do que um ato imposto e interessado (Mauss, M. 1974: 4) ${ }^{17}$.

O ciclo de ritos, implica assim prestação e distribuição para culminar na grande cerimônia dos mortos. Junqueira nota, entretanto, que o círculo que parecia se fechar com as repetições de ciclos não acontece com o ciclo da vida. A ausência de referência explícita à reencarnação, na mitologia Kamaiurá, impede o fechamento do círculo. Talvez, diz ela, isso explique as gerações alternadas dando nome do avô ao neto, nas sucessivas gerações (Junqueira 1978: 05).

\section{O Espaço da Mulher na Sociedade Kamaiurá}

Desde seus primeiros escritos, Carmen Junqueira destacou o papel das mulheres indígenas nas tarefas domésticas, no trabalho da roça, nos cuidados das crianças e insistiu no quanto essas atividades eram pouco reconhecidas pelo conjunto da comunidade. Foi assim pioneira na antropologia brasileira a se interessar pelas relações de gênero nas sociedades indígenas.

No livro "Sexo e desigualdade entre os Kamaiurá e os Cinta Larga" (2002), ela expõe a situação da mulher e do homem nas duas sociedades. Notou que, apesar das diferenças marcantes entre elas, em ambas, as mulheres são relegadas às tarefas ingratas e sem prestígio, circunscritas à rotina doméstica e ao trabalho na roça ${ }^{18}$. Chamava a atenção da etnóloga que, enquanto os homens dominam e controlam o processo social, o espaço das mulheres nesse processo é bastante contido. Aos homens cabiam as tarefas de maior destaque e prestígio como caçar, lutar, fazer a guerra, se tornar líder e pajé, negociar as relações de parentesco com grupos vizinhos, restando à mulher procriar, satisfazer os desejos do companheiro e, principalmente, trabalhar. Esta discrepância se revela também na esfera da estética. Segundo Junqueira, nas festas os homens pintam seus corpos e se tornam verdadeiras esculturas coloridas, enquanto as mulheres se mostram sem nenhum adereço que as torne mais graciosas, e, timidamente, riem pelos cantos da aldeia (Junqueira 2002: 44, 45).

17 Citado por Junqueira (2015: 7,8).

18 Esse artigo se detém na situação das mulheres Kamaiurá. Para maior aprofundamento do modo de vida Cinta Larga ver principalmente os seguintes trabalhos de Carmen Junqueira: Os Cinta Larga, 1984; A relação dos índios Cinta Larga com a vida e com o corpo 1990; Sexo e desigualdade entre os Kamaiurá e os Cinta Larga 2002; Os diamantes do povo Cinta Larga 2010b. 
Apesar da sobrevivência da comunidade depender fundamentalmente da mulher, não só pelo ato de reprodução, mas também por seu trabalho e presença, faz parte do imaginário masculino, a ideia de que a mulher é inferior. Carmen Junqueira relata como nas rodas noturnas, momento de narrar mitos e histórias, as mulheres são com frequência ridicularizadas nas narrativas feitas pelos homens, retratadas como pouco inteligentes. Histórias, diz ela, que sempre se reportam ao sexo, ilustram o desrespeito do homem pela mulher.

A antropóloga reconhece que o papel de dominação masculina nas sociedades indígenas nunca foi ignorado pela antropologia, mas considera que este fato foi pouco estudado. Segundo ela, muitas vezes o tema foi abordado de maneira estereotipada, insistindo na dicotomia que associa o homem à cultura e a mulher à natureza. A pergunta que levanta é se a ênfase dada pela etnologia ao desempenho do homem seria decorrente somente do seu efetivo predomínio na sociedade de tecnologia rudimentar e do uso abundante da energia muscular masculina ou se essa ênfase seria apenas o resultado de uma maneira particular de interrogar a realidade indígena.

Para responder a essa questão recorre aos trabalhos de Margaret Mead que foram pioneiros nesse campo, insistindo no processo de socialização do homem e da mulher e na relação entre cultura e papeis sexuais para explicar a diferença que se estabelece entre homem e mulher em diferentes sociedades. Depois de Mead, outros estudos apoiados numa perspectiva feminista, procuraram responder o porquê da hierarquia que atribui maior valor às atividades masculinas e menor às femininas.

A resposta deve ser buscada no processo de formação do homem e da mulher, cujas diferentes etapas da vida, são determinadas tanto pela biologia como pela cultura. Na sociedade Kamaiurá a menina em reclusão é formada para o casamento e aprende os deveres e conhecimentos de uma dona de casa. O menino, na mesma situação, é formado para tornar-se um bom lutador de Huka-Huka. No término da reclusão, ambos se integram ao mundo do trabalho.

As análises de Carmen Junqueira mostram como o espaço reservado à mulher na divisão social do trabalho dá origem à assimetria nas relações de gênero. Em suas tarefas, o homem tem possibilidade de acumular novas experiências e aprofundar seu conhecimento, tornando-se líder ou pajé, por exemplo. Já os afazeres femininos desenvolvem-se em um circuito fechado de repetições, distante do poder e das atividades que conferem prestígio, e isto durante toda a sua existência.

Essa assimetria decorre também do sistema de parentesco na sociedade Kamaiurá, que embora reconheça igualmente os parentes da linha feminina e da linha masculina, na prática, a linha de descendência masculina é socialmente destacada. Do mesmo modo, o casamento poligínico, onde os homens podem ter várias mulheres ao mesmo tempo, é aceito entre os Kamaiurá, mas os filhos gerados nestas uniões serão sempre identificados como sendo do homem.

A resignação da mulher quando o marido busca outra esposa e ambas passam a conviver sob o mesmo teto, sem que isto altere a obrigação da primeira de suprir a casa com alimentos da roça, fiar algodão, tecer redes, avivar a fogueira do núcleo familiar durante as noites frias e muitas outras tarefas domésticas até o fim da vida, é outro ponto de destaque que configura a assimetria da relação homem e mulher. 
Com a idade avançada, nota Junqueira, a situação evolui e as qualidades de cada um se afloram. Para o homem a velhice chega com a sabedoria, a memória das tradições. Para a mulher a velhice significa conhecimento e saber, principalmente sobre a gestão do corpo e da saúde, como procedimentos de parto e aborto. Finalmente, com a morte as diferenças desaparecem, dando lugar a um ritual comum, à mesma cerimônia, à mesma sepultura. Pertences de um e de outro os acompanham na sepultura, arco e flecha seguem com o homem e o fuso com a mulher. Ambos recebem os mesmos preparos dos corpos para o ritual dos mortos, celebrado na cerimônia do Kuarup (Junqueira 2002).

Carmen Junqueira reconhece que Claude Meillassoux foi um dos primeiros antropólogos a chamar a atenção para o fato das mulheres, nas comunidades domésticas, viverem confinadas em um universo limitado e sem possibilidades de acesso às posições importantes na hierarquia social. $\mathrm{O}$ autor destaca que, nessas sociedades, o controle social se assenta na gestão da reprodução, ou seja, no controle da capacidade da mulher de procriar. Mostrou que, pelas regras que fundamentam a ordem social dessas sociedades, mesmo a capacidade de reprodutora é institucionalmente negada, na medida que só ao homem é dada a capacidade de reproduzir a relação social (Meillassoux 1977: 127). O exemplo se repete na sociedade Kamaiurá, onde os homens mantêm sob seu domínio o livre exercício da política de alianças matrimoniais.

Para Meillassoux (idem: 28), com a detenção total do poder, os homens controlam o conjunto das atividades por meio de recursos ideológicos. Um destes recursos, seria a proibição do incesto, uma noção moral, segundo ele, produzida por uma ideologia ligada à elaboração do poder nas sociedades chamadas domésticas. A proibição do incesto como um recurso de controle masculino sobre as mulheres foi bastante discutida pela antropologia clássica, a partir da tese defendida por Lévi-Strauss (1976a), sobre a troca de mulheres como uma regra da divisão social do trabalho que estabelece dependência mútua entre os dois sexos. A noção de invariante, contida na definição da proibição do incesto de Lévi-Strauss, vai mais tarde influenciar os estudos de Phillipe Descola ${ }^{19}$. Este autor não atribui à oposição entre universo masculino e feminino a mesma importância do que se conhece nas formas de dominação, como as observadas nas diferenças de classe social2 ${ }^{20}$. Já Godelier contraria essa premissa estruturalista afirmando que esta prática não é universal nem representa a maioria das sociedades ${ }^{21}$. A proibição do incesto, diz Godelier, leva a outras possibilidades de incesto logicamente equivalentes.

Essas diferenças nas explicações da base do ordenamento social, onde se inscreve a assimetria na relação homem e mulher, não eliminam uma realidade de fato que é o controle e o poder que os homens exercem sobre as mulheres nas sociedades indígenas.

19 Mais tarde, Lévi-Strauss adota uma outra abordagem da variação, quando concebe que um corpus de mito é constituído, por um lado, por todas as variantes de um mito que preserva as mesmas estruturas e, por outro, por vários mitos, muitas vezes provenientes de sociedades vizinhas, que podem mostrar que se transformam mutuamente em episódios (o que ele chama de Mitemas), dos quais eles inverterão os motivos ou mudarão a função. Descola (2017: 231, 232). Ver também Lévi-Strauss, Les Mythologiques. (1962-1971), principalmente o volume 4, L'homme nu, 1971.

20 Descola entende essas diferenças, não como uma dissociação da representação, mas como unidades de pontos de vista ontológicos analógicos, que dependendo da sociedade podem ser diferenciados. $(2017: 286,287)$.

21 Godelier identifica três possibilidades: ou os homens trocam suas irmãs entre eles, ou as mulheres trocam seus irmãos umas com as outras, ou os grupos trocam homens e mulheres uns com os outros. Segundo Godelier, destas três possibilidades lógicas, Lévi-Strauss manteve apenas uma, colocando o intercâmbio de mulheres entre os homens como a essência do parentesco e, portanto, como um fato universal. (Godelier 1996: 51, 52). 
Contudo, apesar da discrepância quando se compara a situação do homem e da mulher na sociedade Kamaiurá, Junqueira sustenta que existe um espaço para que ambos possam exprimir suas individualidades e que permite às mulheres escapar do controle total dos homens e das rígidas regras estabelecidas pela ordem social. Esse espaço deve ser buscado no que ela chama de "fissuras do tecido social" (Junqueira 2002).

Por conta de um conjunto de mecanismos registrados ao longo de suas pesquisas e que, segundo ela, bloqueiam o radicalismo masculino, geralmente apontados nas análises antropológicas, considera que apesar da pertinência das análises de Meillassoux, só em parte elas se ajustam à sociedade Kamaiurá. Fornece como exemplo, o fato da mulher, em última instância, fazer valer sua vontade na escolha do parceiro, citando os caprichos individuais da jovem esposa que resiste à consumação do casamento. Outro exemplo é o controle que a mulher tem sobre seu corpo na prevenção da gravidez ou na prática do aborto.

Além do mais, em alguns casos, lembra a etnóloga, selada uma aliança importante entre uma mulher e um homem de grupos diferentes, outros grupos competidores se esforçam para rompe-la, instigando a prática do adultério. $\mathrm{O}$ adultério seria assim, menos um ato para quebrar a monotonia da vida conjugal que um recurso usado pela mulher, para forçar o rompimento dos laços matrimoniais. Carmen Junqueira explica esses atos de aparente rebeldia da mulher, como o resultado da individualidade construída no processo de socialização. Segundo ela, diante dessas "fissuras do tecido social", modelos muito fechados como o de Meillassoux ou mesmo o de Lévi-Strauss mostram sua fragilidade para dar conta da total compreensão dos limites do poder de decisão do homem sobre a mulher.

\section{As narrativas míticas e a situação das mulheres}

Ao longo de sua permanência no campo, Carmen Junqueira colheu uma quantidade considerável de mitos e histórias do povo Kamaiurá. A narrativa dos diferentes mitos evidencia a visão de mundo deste povo. Nela, o mundo dos espíritos (mama’e e outras entidades) garante o controle das forças que se manifestam e que ameaçam a ordem social. As relações entre homem e mulher, diz Junqueira, são explicadas e justificadas a partir dos conhecimentos nascidos nesse universo.

Já no mito da criação, as mulheres parecem se dar mal com o criador Mavutisinin. Uma das versões deste mito descreve um mundo encantado onde Mavutsinin, na praia de Morená, transforma troncos em gente. Durante o ato de magia, surgem as mulheres e os troncos regridem à forma original. Desapontado, Mavutsinin atribui a interrupção ao olhar profano das mulheres, matando as intrusas (Junqueira 2002; 2015; 2017).

Diz outro mito que Mavutisinin e a concha Takura’a se amaram nas areias da praia do rio Culuene. Da relação entre eles nasceu uma criança. Quando Mavutsinin soube que se tratava de um menino, de forma brusca e autoritária, retirou a criança da mãe e a levou consigo. Para além da forma ríspida e violenta do homem em relação à concha, o cenário remete à uma regra do sistema de parentesco que atribui ao homem a ascendência sobre a criança gerada em casamentos poligínios.

A supremacia masculina, diz Carmen Junqueira, legitimada pelo primeiro ancestral, vai modelar o comportamento entre os sexos: o macho é superior à fêmea, o homem à mulher. Nas narrativas, são 
inúmeras as interdições às mulheres, justificadas por suas características fisiológicas, como por exemplo, a menstruação, período em que as mulheres se recolhem. Os Kamaiurá consideram o sangue como impuro e explicam a menstruação pelo fato de Mavutsinin ter deixado uma piranha na barriga da mulher, que todo mês mordiscam suas entranham, provocando sangramento.

Junqueira propõe outra explicação possível. Segundo ela, Mavutsinin havia punido as mulheres ao ser surpreendido gerando vida (os troncos) o que é um dom feminino. Por ter usurpado este dom, foi punido pelo olhar profano das mulheres. Vingou-se assim marcando as para sempre com o estigma da menstruação. O sangue por ela vertido evoca o mistério da morte, a negação da vida e a destruição, diz a etnóloga.

Entre muitos tabus concernente às mulheres, um é particularmente importante e diz respeito ao interdito que envolve a flauta Jacuí, instrumento que só pode ser visualizado e tocado pelos homens. Rompido o interdito, as mulheres seriam obrigadas a ter relações com vários homens. Segundo algumas versões, elas seriam todas estupradas. Diz a história que antigamente as mulheres eram donas da flauta Jacuí. Se encantavam com a pureza do som e rendiam homenagem ao mamáe da Jacuí. Os homens, com ciúmes e inveja, decidiram tirar a flauta das mulheres. Com a ajuda do Sol, (kwat) neto de Mavutisin, conseguem fazer grande zumbido. Amedrontadas, as mulheres correm deixando a flauta para trás. Os homens se apoderam do instrumento e, satisfeitos, passaram a ser donos da flauta sagrada. Desde então só eles podem tocá-las.

Esta são apenas algumas das muitas e muitas histórias recolhidas pela antropóloga, onde as mulheres em situações que as colocam em confronto com os homens se rendem a eles atestando a sua fragilidade. Esta incapacidade de enfrentamento é justificada e legitimada na própria cosmologia. Essas histórias contadas por homens, diz Carmen Junqueira, legitimam a maneira como homens e mulheres traçam dois destinos paralelos e modulam a existência de cada um deles.

Alguns mitos e ritos, porém, abrem uma brecha por onde as mulheres podem desafiar os homens. São estes mitos que permeiam as "fissuras do tecido social" abrindo caminho para que a hegemonia masculina seja contestada, como nos casos em que as mulheres se recusam a consumar o casamento ou praticam o adultério. Um desses mitos se refere ao único ritual da cerimônia do Kuarup em que aparece a figura feminina: uma jovem que se encontra em reclusão pubertária, adentra o pátio e recebe do dono da festa castanhas de pequi, que ela oferece em seguida aos líderes dos grupos. O que significa a castanha de pequi distribuída aos líderes visitantes, pergunta a etnóloga? A resposta Carmen Junqueira vai buscar na lenda que dá origem ao pequi e que narra a história de uma paixão vivida entre o jacaré e duas mulheres. Tornaram-se amantes, o amor é proibido, o marido descobre e mata o jacaré com flechas. A pedido do jacaré, as mulheres retiram as flechas e queimam o seu corpo. De suas cinzas nasce o pé de pequi. Kwat (Sol) recomenda passar o pequi na vagina das mulheres o que dá origem ao perfume da fruta. Essa história plena de sensualidade e de interdito exclui as regras matrimoniais para dar lugar aos amores clandestinos, conclui a etnóloga (Junqueira 2015: 15-17).

Ainda que alguns mitos abram espaço para as mulheres desafiarem a supremacia masculina, Carmen Junqueira vê nos relatos míticos, em geral, um elemento conservador, que tem por função perpetuar os modelos de comportamento úteis ao grupo de poder (Junqueira 2002: 44). Relembra 
Roland Barthes (1982), quando afirma que os mitos implicam mensagens ideológicas que eliminam a qualidade histórica das coisas. A tradição materializada nos mitos só faz reforçar o papel passivo da mulher, aceitando, sem contestar, a sua exclusão em várias esferas culturais, como na política, na vida religiosa e no mundo espiritual.

Os mitos se materializam nas narrativas e são elaborados a partir do contexto e do momento histórico vivido por cada povo. As representações dos mitos e dos ritos se adaptam às condições de existência de cada sociedade. Neste ponto, Carmen Junqueira chama a atenção para a forte interação entre a comunidade e a cidade, que permeia aspirações e sonhos de boa parte dos jovens Kamaiurá, que, num futuro próximo, irão conduzir o destino da comunidade. Em decorrência desse contato mais frequente com a sociedade globalizada, as regras se afrouxam para homens e mulheres. Nos últimos anos, algumas mulheres Kamaiurá têm se tornado pajés, apropriando-se assim de uma atividade eminentemente masculina e penetrando na esfera de contato com o mundo espiritual, tradicionalmente reservado aos homens ${ }^{22}$.

O tema das mulheres nas sociedades indígenas volta a ser foco de suas indagações no livro "O tempo e o imaginário - o pajé e a antropóloga: 50 anos de diálogo” (Junqueira 2017). Neste texto, Carmen Junqueira expõe uma série de perguntas sobre as mudanças na ordem social que levaram as mulheres a ocupar um lugar na esfera da espiritualidade, antes reservada aos homens. Suas questões estão menos voltadas para a dinâmica cultural que provoca as mudanças nas sociedades indígenas e mais para as profundezas do inconsciente, bem na linha de James Hillmam (1997), quando pergunta "O que desejam os espíritos ao povoar o sonho feminino? Como entender o fato de que os espíritos, que mantêm relação estreita com os homens e lhes permitem conhecer os segredos da cura xamânica, venham agora dirigir sua atenção às mulheres?”.

Em seguida lança a hipótese: Será que a memória coletiva guarda alguma heresia esquecida ou reprimida? Ou talvez uma interdição indevida que nos tempos de hoje tenha se tornado obsoleta, incendiando o imaginário? Onde teria florescido o desejo de estender a pajelança às mulheres? Teria surgido delas mesmas, na luta silenciosa à procura de maior destaque social ou dos sonhos? Viria dos homens o desejo de compartilhar com as mulheres o árduo trabalho da cura, da localização de feitiços, do diálogo com os espíritos, alguns deles rudes e mesquinhos? (Junqueira 2017: 61, 62).

Foi o próprio xamã Tacumã, percebendo que seu filho não apresentava o dom do xamanismo, que iniciou sua filha na prática da pajelança.

Tratando de práticas tão intimamente ligadas ao imaginário, a antropóloga preferiu buscar nesse profundo universo a explicação para as mudanças ocorridas no universo feminino. Sendo o imaginário formado por camadas que se sobrepõem, ninguém pode estar seguro dos próprios desejos, nem homens, nem mulheres e nem espíritos.

22 Essa apropriação das atividades masculinas pelas mulheres indígenas se observa também em outras comunidades. Na sociedade Yanomami as mulheres passaram a ser guias turísticas e subir o Pico da Neblina, morada dos espíritos onde antes as mulheres não podiam pisar. Cf. Marcelo Leite, As Montanhas Sagradas dos Yanomanis. Folha de São Paulo, 10 de setembro de 2017. Do mesmo modo, algumas mulheres Cinta Larga, antes de matar uma galinha, passaram a entoar o canto cerimonial berewa, entoado somente pelos homens em tempos de guerra, o que não ousariam fazer em uma cerimônia pública, tempos atrás. (Junqueira 2002). 
Para justificar essa premissa, se apoia na obra de Andrei Tarkovski, no filme Stalker. Nele existe uma zona proibida, na qual o desejo mais profundo da pessoa é realizado. "A mera entrada na Zona permite uma reflexão sobre si mesmo, despertando nos fracos e desiludidos alguma força espiritual" (Junqueira 2017: 62). A reflexão sobre si mesmo ocorre porque, como mostra Tarkovisk, a entrada na Zona interdita (o inconsciente, o mistério?) atendia, na verdade, o mais profundo desejo do consulente, aquele não revelado, e não o que ele pensava ser o maior de seus desejos. Confrontado com o seu real desejo, aquele saído das profundezas do imaginário, do inconsciente, o consulente suicidou-se ${ }^{23}$. Talvez por ser confrontado consigo mesmo e com a tentativa de se auto enganar, afirma Junqueira.

Qual a relação do desejo inconsciente revelado quando se entra na zona interditada do profundo universo do imaginário com o fato das mulheres indígenas penetrarem no universo dos espíritos reservado ao domínio masculino, pergunta a etnóloga.

Carmen não abre o debate neste texto, apenas sugere como uma resposta possível a luta silenciosa travada pelas mulheres, em busca de mais destaque social. A luta das mulheres indígenas em defesa de seus direitos vem de um longo processo. $\mathrm{O}$ contato com a sociedade globalizada, onde as mulheres têm conseguido mais espaço social é, sem dúvida, um incentivo de peso para que as mulheres se organizem em associações para obter mais reconhecimento e mais possibilidade de agir nas diferentes esferas da sociedade. Os sonhos acontecem, nascem do inconsciente, mas só se realizam através de ações que levem a um maior reconhecimento social, que começou de forma silenciosa e ganhou relevo nas diferentes sociedades indígenas. Carmen Junqueira não somente é consciente desse processo, como dele participou incentivando, em muitos momentos, as mulheres indígenas não só a criar suas próprias instituições, mas também a prosseguir com as práticas de pajelança.

\section{O Imaginário e o Simbólico na configuração do tempo Kamaiurá}

Segundo Carmen Junqueira, para o povo Kamaiurá, a realidade contém três dimensões: o mundo sensível habitado pelos humanos, a aldeia dos mortos, onde as almas passam o tempo dançando e comendo, e a dimensão povoada por espíritos (mama’e) que vivem nas matas, nas águas e nos ares.

Em seu livro "O tempo e o imaginário - o pajé e a antropóloga: 50 anos de diálogo" (2017), Carmen Junqueira analisa um vasto material sobre mitologia, iniciação à pajelança, rituais e atividades que vão definir a tradição Kamaiurá. Com a intenção de verificar como o imaginário atua e modela as relações naquela comunidade, a etnóloga se dedica, principalmente, à análise de mitos e narrativas relatados por Takumã Kamaiurá, cacique da aldeia de Ipavu no alto Xingu ${ }^{24}$.

Carmen parte da premissa de que os mitos que dão vida aos homens e aos animais, às paixões e às vinganças são animados pelo imaginário. $\mathrm{O}$ imaginário atua assim como legitimador da vida social,

23 Na obra de Tarkovski, o personagem Diko-óbraz penetra na sala para pedir a ressureição do irmão assassinado por sua culpa, mas em seguida se encontrou coberto de riquezas. Vendo que seu pedido não correspondia ao seu verdadeiro desejo Diko-óbraz enforcou-se.

24 Reconhecido no Brasil e no exterior, Takumã Kamaiurá foi cacique da aldeia de Ipavu por cerca de 40 anos e um dos pajés mais respeitados do Xingu. Carmen o conheceu em sua primeira viagem ao Xingu, em 1965. O livro pode ser visto também como uma homenagem a este grande amigo e seu informante durante 50 anos. Takumã faleceu em 2014. 
inclusive redefinindo costumes e seus respectivos símbolos. Para sustentar suas ideias, se apoia em três autores que, segundo ela, a ajudaram a ampliar a noção de mito, imaginário e inconsciente. São eles, o teórico literário e escritor italiano Ítalo Calvino, o psicólogo e analista americano James Hillman e o antropólogo francês Maurice Godelier.

Para Calvino, (1977), a criação do mito é fruto de uma fábula que o contador de história elabora, sempre a aperfeiçoando, com palavras cada vez mais ricas de significado. Na repetição do exercício, diz Calvino, ocorre a iluminação do inconsciente: a reserva de palavras, valores, interdições, heresias esquecidas, reprimidas aflora na mente do narrador e a história atinge o significado perfeito do mito. A transmutação é consumada quando a fábula profana torna-se um mito sagrado.

Já o psicólogo e psicanalista americano James Hillman (1997), influenciado pelo pensamento de Carl Jung, busca conceituar a noção de psicologia arquetípica. Segundo o psicanalista as grandes questões filosóficas giram em torno das relações entre o visível e o invisível. A vida e a morte, o sagrado e o profano. O abismo entre o visível e o invisível é criado ao mesmo tempo pelas crenças religiosas e pela mentalidade filosófica. A primeira separa os céus e a terra, a vida presente e a vida após a morte. A segunda cria a dicotomia entre mente e matéria. Para o autor, uma maneira de atravessar os dois mundos e encontrar o ponto de ligação entre o visível e o invisível é se apoiar na matemática, na música e no mito, na medida que eles transpõem o mistério do invisível, ou seja, do imaginário, para processos visíveis.

Depois de acatar a ideia do contador de história, que com os poderes narrativos atinge a transmutação da fábula profana em mito sagrado, e de introduzir a noção de mundo invisível para explicar a força do imaginário, por trás das narrativas mitológicas, Junqueira vai se servir da visão antropológica de Maurice Godelier quando este autor estabelece a ligação entre o imaginário e o simbólico. Introduzindo o simbólico, incorpora-se o efeito de consciência que tem seu fundamento na sociedade e na história. $\mathrm{O}$ efeito de consciência explica a correspondência estrutural que existe constantemente entre forma do pensamento mítico e forma da sociedade (Godelier 1981: 77).

Segundo Godelier, o imaginário é do domínio do pensamento. O imaginário é antes de tudo um mundo ideal, feito de ideias, de imagens e de representações de todos os tipos, que têm suas origens no pensamento (Godelier 2010: 43). Este produz o real social combinando duas partes dele mesmo, dois poderes distintos que se completam sem se confundir, que são: a capacidade de representar, de imaginar e aquela de simbolizar, de comunicar as coisas reais ou imaginárias.

Godelier contesta a primazia do simbólico sobre o imaginário e sobre o real, defendida por Lévi-Strauss, o que é plenamente compartilhado por Carmen Junqueira ${ }^{25}$. A esfera do simbólico implica o conjunto dos meios e dos processos pelos quais realidades ideais se encarnam ao mesmo tempo em realidades materiais e em práticas que lhes conferem um modo de existência concreta, visível, social. O imaginário, para adquirir existência manifesta e eficácia social deve se encarnar em signos e práticas

$25 \mathrm{Na}$ leitura de Descola, para Lévi-Strauss, a atividade inconsciente do espirito explica a estrutura e o funcionamento dos sistemas simbólicos, sendo a variação de seus conteúdos um efeito contingente dos meios naturais e históricos no seio dos quais eles se desenvolvem (Descola 2017: 227). Para Godelier o problema é saber se podemos construir representaçôes mais adequadas desta realidade afirmando que o simbólico prevalece sobre o imaginário. Para ele, é a perspectiva oposta que deve ser adotada. São, antes de tudo, as diferentes maneiras pelas quais os homens imaginam suas relaçóes entre si, e com o que chamamos de natureza, que distinguem tanto as sociedades como os períodos durante os quais alguns símbolos continuam a existir (Godelier 1996; 2010). 
simbólicas variadas que dão nascença às instituições que as organizam, mas também a espaços onde elas se exercem. (Godelier 2010: 43, 44). É o imaginário compartilhado, a curto e a longo prazo, que mantém os símbolos vivos (idem: 48, 49).

Podemos entender assim que, para Carmen Junqueira, o imaginário é dotado de três dimensões: a narrativa, a do inconsciente e a simbólica. Na dimensão narrativa, é o recurso hermenêutico que se põe em marcha, quando o contador de história desencadeia um processo reflexivo sobre o objeto da narração, selecionando elementos, retrabalhando ou introduzindo outros, de modo a aprimorar cada vez mais a trama dos eventos. A dimensão inconsciente diz respeito ao mundo invisível (a psique, a alma, a morte) que povoam as narrativas mitológicas. Com a dimensão simbólica introduz a dimensão social do imaginário.

Para Carmen Junqueira, uma das maneiras de se avançar na compreensão da vida social é ter em mente a noção de símbolo como criação social. Costumes, leis, hábitos, normas são produtos - criação - de uma tradição especifica. Criado no convívio social, o imaginário se aloja na memória coletiva, sendo enriquecido com novas aquisições, revisado pelas novas gerações com o auxílio do que ela chama os intelectuais da comunidade - os grandes pajés.

Tendo exposto sua compreensão do imaginário, a etnóloga passa a definir a concepção do tempo Kamaiurá, fazendo um contorno pelos mitos. Divide a temporalidade em três períodos: O primeiro O Tempo ancestral - corresponde à criação do homem e compreende um curto período na história Kamaiurá. O segundo é referente ao Tempo das criações, época em que ocorreram variadas modificações no habitat primitivo. Este tempo abrange um longo período e nele surge praticamente toda a mitologia Kamaiurá. O Tempo moderno tem início quando Takumã Kamaiurá é convocado pelos espíritos para se tornar pajé, realizando grandes curas e feitos, e se encerra em 2014 com a sua morte ${ }^{26}$.

Resumindo os três períodos, temos que no tempo dos ancestrais o mundo era habitado por matas, rios, lagoas e campos, animais da terra, da água e dos ares e também por mamáes, espíritos poderosos guardiões das espécies animais, das plantas e dos objetos rituais. No tempo das criações surgem praticamente todos os seres da mitologia Kamaiurá. Carmen Junqueira se detém na análise de quatro importantes mitos das criações: o nascimento de Kwat e Iay (Sol e Lua), a obtenção do dia, o reconhecimento do poder dos espíritos e a criação dos povos alto-xinguanos (Kuarup).

$\mathrm{Na}$ narrativa mítica, o filho de Mavutsinin, nascido da concha, que também se chamou Mavutsinin, será confrontado com outras forças igualmente potentes. Entre elas estaria a onça, da linhagem mais poderosa da Terra e a quem Mavutsinin foi obrigado a ceder suas duas filhas. Uma destas filhas gerou dois meninos gêmeos, Kwat (Sol) e Iay (Lua). Sol e Lua seriam filhos da onça com a filha de Mavutisinin. As suas filhas, nota Junqueira, surgem para que a aliança com a onça seja selada pelo casamento.

Os mitos de organização do mundo Kamaiurá se sucedem no tempo da criação, no texto da antropóloga ${ }^{27}$. Com a introdução do mito do urubu real, dono da luz, Kwat e Iay obtém o dia e a luz do

26 O tema do tempo é recorrente na antropologia indígena. No que concerne à sociedade Kamaiurá, Diego Fausto Ramos (2010) definiu o tempo como "categoria elementar do conhecimento, um produto eminentemente social". Entende que o tempo Kamaiurá encontra sua representação ideal nos momentos de passagem de um estado para outro. (ex. dos ciclos do sol, da lua, das plêiades e das estações climáticas).

27 Para aprofundamento dos mitos ver Junqueira 2015; 2017 e Agostinho 1974. 
sol, cuja claridade plena será associada ao aparecimento do cocar de penas da arara vermelha e, de forma mais intensa, do cocar com penas amarelas.

A revelação do mundo dos espíritos-pajés à sociedade surge em outro mito, onde Kwat e Iay testam os conhecimentos de cura dos pássaros-pajés. Obtendo sucesso em suas provas, todos são reconhecidos como bons pajés.

Por fim, a narrativa do Kwarup, já citado anteriormente, dá conta da criação dos povos alto-xinguanos e dos seus símbolos de identidade concebidos por Mavutisin. Os Kamaiurá, convocados em primeiro lugar, escolheram o arco preto, os Kuikuro o colar de lâminas de concha, os Kalapalo o cinto de discos de caramujo e os Waurá a panela de cerâmica.

O tempo mítico remete à história das origens. Na narrativa mítica o presente é remetido ao passado. Carmen Junqueira vai chamar esse tempo que esclarece e explica o novo como uma espécie de "tempo abolido", porque idealizado pelo imaginário. Esse tempo mítico é o que dá fundamento à existência Kamaiurá, porque remete o presente ao passado e abre para as novas gerações a explicação de suas origens.

O terceiro período corresponde ao tempo da formação dos pajés, cujo papel na comunidade tem sua importância na cura de doenças enviadas pelos espíritos, na possibilidade de controlar tempestades e outras catástrofes naturais, de desvendar a presença de feiticeiros ou eliminá-los através de outros rituais mágicos e também de interpretar sonhos.

A narrativa etnográfica dá conta de como espíritos-pajés observam de perto o comportamento humano, tanto para punir transgressões rituais, quanto para escolher aquele que se tornará pajé. Para ilustrar o processo de iniciação à pajelança e a reconstrução do universo fantástico que envolve toda a aldeia, Carmen Junqueira cede a palavra a Takumã Kamaiurá, quem narra sua relação com o mundo espiritual. O grande cacique conta que foi chamado, em diferentes épocas da sua mocidade, por três diferentes espíritos pajés: o mamảe Kapaje (passarinho), Ajangu (mama’e do mato que joga doença, mas não mata) e, finalmente, o mais importante deles, Timukuiari (peixinho agulha), que o tornou um grande pajé. O processo de iniciação é doloroso e Takumã passa por inúmeras provas, adoecendo até ficar à beira da morte, antes de se tornar um pajé. Sua grandeza e a força de seus mamáe são relatadas em vários feitos por ele realizados e reconhecidos pelos seus e por todos que o conheceram desde a época dos irmãos Villas Boas. São casos de cura, mas também de resolução de casos tidos como perdidos por outros pajés.

Carmen Junqueira segue narrando a atmosfera impregnada de magia em que todos viviam na aldeia de Ipavu. Ela mesma, que desde suas primeiras estadias costumava se hospedar na casa de Takumã, diz que um dia, ao acordar, viu um índio em pé à beira da rede do irmão mais novo do xamã. Soube depois que se tratava de um mamáe que estava iniciando este irmão de Takumã.

Segundo a etnóloga, as narrativas míticas Kamaiurá constituem a parte central da religião e expressam a estreita relação entre arte e política, entre estética e poder. As narrativas míticas se atualizam nos rituais que são fundamentais para a identidade Kamaiurá. É na repetição do mito, das cerimônias e rituais que os povos relembram acontecimentos ancestrais, fortalecem a memória, afastam o perigo do esquecimento. 
Junqueira reconhece, todavia, que mitos são esquecidos, rituais sofrem modificações e cerimônias ampliam e diversificam seu alcance. Lembra que, desde 1945, um amplo e variado material etnográfico permite registrar mudanças ocorridas na comunidade ${ }^{28}$. Atribui essas mudanças à dinâmica cultural que promove novos modelos de comportamento e novas práticas e nova percepção do mundo. Faz parte de um processo natural, que não é exclusivo da sociedade Kamaiurá, mas atinge qualquer sociedade, diz ela. Da dinâmica cultural sobrevém a renovação da organização social. Na sociedade Kamaiurá esta renovação se nota quando novos hábitos surgem, enquanto outros são abandonados. A introdução da internet é a mais significativa mudança cultural observada nos dias de hoje. O aumento do consumo de bens industrializados também implica maior dependência do mercado capitalista. Mas o maior desafio parece ser reservado à capacidade de a geração mais velha manter a liderança e a legitimidade de suas práticas.

A etnóloga sugere que essas mudanças promovem novas aquisições culturais que podem abrir uma nova etapa na vida comunitária e renovar o convívio social. Um exemplo disso está no fato já relatado anteriormente de algumas mulheres Kamaiurá terem se tornado pajés, avançando na direção do grau mais alto de contato com o mundo espiritual, tradicionalmente reservado aos homens.

De qualquer modo, conclui Junqueira, quaisquer que sejam os conteúdos de idealidades imaginárias e as dimensões simbólicas dos desafios que dão origem às relações sociais, eles não são somente imaginários nem puramente simbólicos. Segundo a antropóloga, os desafios podem se expressar em uma série de questões às quais a iniciação das mulheres à pratica da pajelança é apenas uma entre as respostas que a sociedade Kamaiurá oferece em reconhecimento ao processo de mudança, independente se ela converge ou não com as narrativas míticas do tempo da criação. Mas uma tal conquista da parte das mulheres não é sem consequência para a preservação do ordenamento social e cultural. O espaço que será reservado ao pajé no mundo indígena é apenas uma das questões. Outra é como as novas gerações que são atraídas pela cidade e pelo mundo cada vez mais globalizado vão conviver com as práticas de pajelança.

De todo modo, os símbolos só sobrevivem e só continuam a ser socialmente pertinentes se fizerem sentido para todos ou para uma parte da sociedade. Daí resulta, afirma Carmen Junqueira, que o objeto da antropologia é de compreender e de fazer compreender as diferentes maneiras das sociedades indígenas pensar, agir e organizar a vida, numa sociedade cada vez mais próxima do mundo globalizado.

28 Entre as mudanças registra se a tonsura que os homens faziam no topo da cabeça e que foi abandonada; a localização das redes - a do homem colocada acima e sobre a da mulher - que não mais se vê; a cerimônia do Kwarup passou a ser realizada em homenagem a pessoas não indígenas; o propulsor de flecha deixou de ser usado no jogo do Jawari; alguns mitos coletados por Villas Bôas não são mais lembrados. Do mesmo modo, a memória da riqueza cultural transmitida pelos velhos, à noite na beira da pequena fogueira, foi substituída pelos aparelhos de televisão (Junqueira 2017:54). 


\section{Mundo animal e mundo humano ou a relação natureza e cultura}

No tempo dos mitos, quando a vida foi criada, todos os seres se comunicavam numa mesma língua, o que facilitava a união entre espécies diferentes. As diferenças só eram perceptíveis através dos nomes das plantas, dos animais, dos astros. Esta constatação levou a antropologia indígena, em geral, a tentar explicar como na visão de mundo dos povos nativos, a fronteira entre mundo animal e mundo humano não é perceptível, como se nota na compreensão de mundo ocidental.

Para Carmen Junqueira, na narrativa mitológica, a cultura e a natureza formam um sistema uno e coerente onde residem criações como os seres humanos, os espíritos (seres invisíveis) e certos animais, plantas e a matéria inorgânica de modo geral. Por trás da diversidade aparente de seres, existe uma semelhança que nivela todos no mesmo patamar: homem, plantas, animais. A diferença de aspecto pouco significa, o que explica a não necessidade de justificar os casamentos de homens e mulheres com onça, jabuti, gavião, arara, saúva, jacaré, abelha porque, de toda evidência, se trata do encontro de dois seres constituídos de igual fundamento, ou seja, todos concretizavam a vida, eram mortais e tinham uma alma (Junqueira 2004).

Segundo Junqueira, ao nomear os fenômenos da natureza, concedendo-lhes características humanas, os índios estão destacando a unidade do cosmo. Essas constatações levam a antropóloga a afirmar que não é correto tratar homem e natureza como coisas separadas, uma vez que os próprios índios não estabelecem qualquer ruptura entre eles (Junqueira 2004).

As diferentes intrigas envolvendo humanos e não humanos mostram que aves, peixes e outros animais e plantas, em sua essência, são seres espirituais, têm mamaé. Homens e animais compartilham substâncias comuns. Mas alguns animais são dotados de poder para curar e conceder favores ao homem. Outros são destruidores, capazes de provocar doenças. Carmen Junqueira lembra que a existência do pajé como especialista em cura, deve-se à ajuda dos espíritos animais, vegetais e objetos cerimoniais. São eles que ensinam as práticas da pajelança. No mais das vezes, diz ela, sem a ajuda do espírito do animal protetor, é impossível ao pajé realizar suas práticas de cura e de resolução dos problemas que afligem a comunidade. Os espíritos animais são também dotados de personalidade e temperamento variáveis. O pajé aprende que, para obter favores dos espíritos animais, deve fazer prova de sacrifico (se abster de certos alimentos, consumir pimenta, afastar-se das mulheres).

Muitas passagens dos escritos de Carmen Junqueira sobre o universo Kamaiurá, e o seu mergulho na cosmologia indígena, retomam e renovam estudos clássicos desde o início da antropologia (Frazer 1982; Durkheim 2003). Contemporaneamente este tema também é retomado pelo antropólogo Philippe Descola $(2005 ; 2017)$, apesar das diferenças de perspectivas teóricas que marcam os trabalhos dos dois autores. Adotando uma perspectiva com forte inspiração estruturalista, Descola desenvolveu o que ele chama de "esquemas da prática", que são formas de comportamento em relação aos humanos 
e não humanos ${ }^{29}$. Seu modelo, aponta uma continuidade e descontinuidade entre os seres humanos e não humanos, cuja arquitetura são as diferentes formas de identificação (animismo, totemismo, naturalismo e analógico $)^{30}$. Para ele, a noção de natureza, central para a antropologia, não é universal. Não existem uma natureza e várias culturas, mas formas de composição de vários mundos e várias naturezas. Para além da separação entre cultura e natureza, é preciso apreender as formas de composição desses mundos ou dessas naturezas, afirma o autor.

Apesar de sua compreensão do totemismo ter inspiração direta em Lévi-Strauss, Descola rejeita a grade de análise classificatória deste autor para privilegiar formas de comportamento e estilos de interação com não-humanos ${ }^{31}$. As relações entre entidades do mundo transcendem as diferenças morfológicas e funcionais aparentes para enfatizar um fundo comum de similitudes ontológicas. Não se trata mais, como postulou Lévi-Strauss, de uma homologia entre classes naturais e classes culturais, mas de um pertencer comum de certos humanos e certos não humanos a uma classe definida por uma qualidade original ${ }^{32}$.

A partir desse modelo, Descola vê na narrativa mítica uma experiência de pensamento que mostra os não humanos com uma interioridade como a nossa e os corpos bastante diferentes. Sendo uma experiência do pensamento, os mitos são operações abstratas, a exemplo do contrato social da filosofia política, para acabar com o estado da natureza e legitimar a soberania política. Assim como o estado da natureza é uma ficção teórica que nunca existiu, segundo o próprio Rousseau ${ }^{33}$, o mito é uma ficção necessária para que uma condição ontológica receba a expressão imaginada de sua realização (Descola 2017: 186).

Descola compartilha a ideia de Lévi-Strauss segundo a qual a atividade inconsciente da mente explica a estrutura e o funcionamento dos sistemas simbólicos. As variações de seus conteúdos são um efeito contingente dos ambientes naturais e históricos no seio do qual eles se desenvolvem. Assim procedendo, considera que não se pode postular a abordagem do universo indígena a partir unicamente do imaginário social porque, apesar da diversidade, em contextos ecológicos muito diferentes se encontra o mesmo tipo de relação com não humanos, o que mostra que a relação empírica entre o tipo do meio ambiente e o tipo de representação não funciona (Descola 2017: 197).

29 Os "esquemas da prática", entendidos como estruturas cognitivas geradoras de inferências, se apresentam na forma de um sistema de contraste entre esquemas distintivos: animismo, totemismo e naturalismo, aos quais se junta o analógico, resultado dos três primeiros, e que se refere a um sistema no qual os humanos pensam que todos os elementos, tanto do mundo físico como moral, são diferentes, descontínuos. (Descola 2017). Ver principalmente, cap. 3. La Diversité de Nature.

$30 \mathrm{O}$ animismo é o ponto de partida e ancoragem etnográfica da reflexão do autor e é definido pela continuidade de interioridade entre humanos e não humanos e a descontinuidade das disposições físicas. No totemismo as espécies animais constituem objetivações exemplares de uma relação de identidade física e moral entre certas entidades do mundo.

31 Segundo Descola, no totemismo, tal qual concebido por L. Strauss, antes de tudo, é a relação de subsunção de um grupo sob uma qualidade que designa tanto os seres humanos como os não humanos deste grupo e não a relação de um grupo para um animal. (2017: 214).

32 Descola abdica assim da definição de totem de Lévi-Strauss que, segundo ele, persiste na separação entre natureza e cultura. Esta separação será banida da antropologia de Lévi-Strauss em sua obra Mythologiques, composta de 4 volumes (1962-1971).

33 No Discurso sobre a Origem das Desigualdades entre os homens, Rousseau desenvolve uma metáfora sobre o estado da natureza, o estado pré-civilizatório, onde os homens viviam felizes. Este autor funda o estado de natureza sobre raciocínios hipotéticos e condicionais e fez disso um princípio universal de explicação. Rousseau não empregou o termo "bom selvagem", com frequência lhe atribuído. Nos Diálogos, Rousseau suscita a visão de um mundo ideal intemporal que oferece a imagem da verdadeira natureza do homem. O estado da natureza, primitivo e original, é menos para Rousseau, uma idade Historicamente localizada do que uma hipótese sobre a natureza essencial do homem. Cf. « Rousseau Juge de Jean Jaques - Dialogues”, nota 4 da p. 934. Edição e notas por Robert Osmont. In: Rousseau, 1959. 
Essa compreensão se confronta com o postulado de Carmen Junqueira segundo o qual a narrativa mítica está intrinsicamente ligada ao imaginário. Segundo a autora, o imaginário atua na sociedade modelando relações sociais, redefinindo costumes e seus respectivos símbolos, tornando se assim parte da realidade social.

A questão de como os mitos influenciam na organização social dos povos é uma consequência desse entendimento. Com isso, Junqueira identifica nas inquietações que povoam os mitos a missão de orientar a conduta de cada um para questões do dia-a-dia, exemplificando o que é certo ou errado, o que é passível de punição ou de gratificação e de explicar o fenômeno da vida, como surgiu e qual é sua essência. Os desdobramentos dessa reflexão, segundo ela, são mostrados nos mitos que falam da instauração dos grupos sociais, das diferenças entre povos e das características de espécies animais.

No que concerne a compreensão do tempo mítico, em seus estudos sobre o povo Achuar, Descola considerou que ele implica uma espécie de amnésia do passado imediato e um aplanamento da duração. O autor chamou de "tempo aplanado", o tempo mítico que remete o povo indígena a um momento da condição de possibilidade de um presente imutável. Como foi mostrado acima, essa mesma defasagem entre o tempo do mito e o da geração presente foi analisado por Carmen Junqueira como "tempo abolido", idealizado pelo imaginário. Para ela, com o "tempo abolido", fecha -se um grande círculo que mantém o vínculo passado e presente.

As análises de Philippe Descola têm grande intimidade com a antropologia desenvolvida por Eduardo Viveiros de Castro e em várias passagens do seu livro Descola faz referência ao trabalho do antropólogo brasileiro e ao frutuoso debate estabelecido entre ambos. Em sua teoria sobre natureza e cultura, Viveiros de Castro procura identificar as equivalências entre o pensamento dos povos nativos e aqueles desenvolvidos pela academia. Para ele, na perspectiva indígena, todos os seres - animais, plantas e espíritos - possuem uma mesma cultura, ou espírito, e o que os diferencia é a sua natureza, seus corpos, o que o leva a conceber a noção de multinaturalismo, para contrapor com a ideia hegemônica de multiculturalismo ${ }^{34}$.

Os modelos de Philippe Descola e de Eduardo Viveiros de Castro, se inspiram nas obras de Lévi-Strauss sobre a mitologia, para postular que o conhecimento dos povos indígenas pode ser classificado ao lado das grandes tradições filosóficas ${ }^{35}$. Ao adotarem a perspectiva em termos de pluralidade de mundos, esses modelos abrem novas perspectivas de análise, quando tomam como ponto central as interações múltiplas nas quais as pessoas vivem e que devem ser levadas em conta para tomar decisões e agir no social e não sobre o que molda suas escolhas para responder as essas interações, como a motiva-

34 Ver, principalmente, Viveiros de Castro, E. 2002 e as considerações tecidas por Renato Sztutman na revista Sexta Feira, onde faz uma síntese crítica e precisa da obra de Viveiros de Castro, disponível em: www.antropologia.com.br/comu/colab/c13-releasevcastro.pdf. Ver ainda Oscar Calavia Sáez (2012) onde, respondendo às críticas contundentes ao perspectivismo tecidas por Terence Turner (2009) e Alcida Rita Ramos (2010), defende que o modelo, ao mesmo tempo que fornece variedades interpretativas à analise etnológica, quando foca as diferentes situações em que se encontram os indígenas, de diferentes etnias, ele adquire um significado político quando possibilita o surgimento de novas lideranças, novos pontos de vistas não ditados, necessariamente, pela etnologia clássica e a ação indigenista, quando postulam que somente em nome de coletivos pode-se avançar nas reivindicações indígenas (2012: 18).

35 Nesse sentido, Manuela Carneiro da Cunha entende que tal perspectiva considera o pensamento dos povos indígenas como parceiro de uma rede de conhecimento sobre o mundo. A antropóloga, que adota a perspectiva de pluralidade do mundo, com base no modelo de Descola, para conceber a análise das formas de conhecimento cientifico e prático, considera que essa perspectiva é menos pragmática e mais ontológica, porque questiona sobre o que existe, e também ético porque postula qual é o seu valor. (Carneiro da Cunha 2012: 41). 
ção por interesses de classes, por exemplo. Eles favorecem a descrição de sequências de ações curtas, de situações especificas de interação e não a análise das cadeias históricas de interdependência que ligam os atores em suas condições de existências, como as relações de dominação e subordinação.

O caminho teórico percorrido pela etnóloga Carmen Junqueira não se fixa em um modelo único, mas se serve de uma sorte de transdisciplinaridade que transparece nas escolhas dos conceitos e a concepção do imaginário é só um exemplo. A forte influência da antropologia econômica no início de seus trabalhos a levou a privilegiar as dimensões sociais e culturais da existência dos Kamaiurá, como as formas de produção, as alianças matrimoniais, os sistemas de troca, o exercício do poder político, os ritos e os mitos como fundamento dessa existência. Nesse item, por exemplo, seguindo a linha de Godelier, para ela importa identificar o papel ativo do conteúdo das relações históricas específicas na produção do pensamento mitológico.

Sem dialogar diretamente com a antropologia de inspiração estruturalista, Carmen Junqueira, em muitos momentos, mostra-se bastante crítica a modelos teóricos que reservam pouco espaço às condições históricas dos eventos estudados, privilegiando as estruturas internas dos fenômenos em detrimento de suas perspectivas históricas e das consequências que delas emanam. Uma das críticas que se fazem ao estruturalismo, é que seu método faz passar para segundo plano a questão da causalidade histórica (meio ambiente, técnica, econômica, política, ideológica), para privilegiar os princípios que regem as semelhanças e diferenças das práticas, de sistemas ideológicos e de valores.

Embora o caráter a histórico dos modelos apresentados por Viveiros de Castro e também por Descola se confronte com a perspectiva histórica adotada por Carmen Junqueira, as divergências não impedem que as observações de campo cheguem a semelhanças consideráveis, no estudo dos mitos por exemplo, quando mostram a dificuldade de conceber uma separação entre natureza e cultura, durante muito tempo sustentada pela antropologia. As similaridades nas observações e as diferenças no percurso da análise oferecem matéria para reflexão e remetem à fala de Marcel Mauss dirigida ao antropólogo britânico Meyer Fortes, a propósito de suas diferenças teóricas: "Pouco importa a rede jogada ao mar, sempre se pescará alguma coisa" ${ }^{36}$.

$\mathrm{Na}$ concepção de Viveiros de Castro (2002), é por meio da atividade dos xamãs que se pode entrar na essência do mundo das ontologias onde os humanos veem os animais como animais, e os animais veem a si mesmos como humanos. Em suas análises, Carmen Junqueira afirma que somente ao pajé é dado frequentar o mundo dos animais e dos espíritos fazendo a ligação entre o mundo visível e o mundo invisível. Uma e outra dessas observações levam à reflexão sobre a prática etnológica e o quanto é fascinante perceber que nela, quando bem realizada, os dados teimosamente parecem, a todo instante, querer se sobressair aos modelos teóricos.

Em sua perspectiva histórica, Junqueira estabelece que cada período vai indicar os tipos de relações estabelecidas entre os povos. Essas relações têm forte impacto na vida social, política e espiritual de cada um e vão delinear a forma de vida em sociedade. Para ela, é fundamental entender como se dá

36 Citado por Manuela Carneiro da Cunha (2012: 58). 
a relação entre sociedade indígena e sociedade global, para apreender as mudanças que ocorrem nessas sociedades e suas consequências.

O que se constata ao término deste texto, é a importância de se levar em conta a necessidade de ajustamento da reflexão metodológica e histórica a partir da experiência no campo e dos questionamentos intelectuais próprios à ambição crítica das ciências sociais. A antropologia desenvolvida por Carmen Junqueira não se atém à construção de um modelo teórico, mas pode se prevalecer de, ao longo dos anos, ter procurado um constante remanejamento do legado teórico das ciências sociais, para dar conta das novas situações e dos novos desafios que emergem do trabalho empírico, quer sejam decorrentes do confronto entre a sociedade Kamaiurá e a sociedade global ou da própria dinâmica cultural interna ao grupo, em grande parte influenciada por este confronto. Sua antropologia inovou quando, no final da década de 1960, colocou o conhecimento antropológico a serviço dos direitos humanos do objeto que escolheu estudar. Com isto construiu o modelo da antropologia engajada no Brasil.

Lindinalva Laurindo Teodorescué doutora em sociologia pela École des Hautes Études en Sciences Sociales, Paris e membro do Núcleo de Estudos de Etnologia Indigena, Meio Ambiente e Populações Tradicionais, PUC-SP. Atuou com pesquisadora cientifica no Instituto da Saúde da SES-SP e no Centre de Recherche Médecine et Sciences Sociales, CERMES, Paris.

\section{REFERÊNCIAS BIBLIOGRÁFICAS}

AGOSTINHO, Pedro. 1974. KWARÍP, Mitos e Ritual no Alto Xingu. São Paulo: EPU.

BOLTANSKI, Luc et THÉVENOT, Laurent. 1991. De la Justification - Les Economies de la grandeur. Paris: Gallimard.

CALAVIA SÁEZ, Oscar. 2012. “Do Perspectivismo ameríndio ao índio real”. Campos 13(2): 7-23.

CALVINO, Ítalo. 1997. "A combinatória e o mito na arte da narrativa”. In: Atualidade do mito. Tradução de Carlos Arthur R. do Nascimento. São Paulo: Duas Cidades.

CARNEIRO DA CUNHA, Manuela. 2012. Savoir autochtones: quelles nature, quels apports? Leçon Inaugurale du Collège de France. Paris: Fayard.

DESCOLA, Philippe. 2005. Par-delà nature et culture. Paris: Gallimard.

DESCOLA, Philippe. 2010. Diversité de nature, diversité de culture. Paris: Bayard.

DESCOLA, Philippe. 2017. La Composition des Mondes. Entretien avec Pierre Charbonnier. Paris: Flammarion. 
DURKHEIM, Émile. 2003. As formas elementares da vida religiosa. São Paulo: Martins Fontes.

FRAZER, James. 1982. O Ramo de Ouro. Rio de Janeiro: LTC.

GALVÃO, Eduardo.1979. Índios e Brancos no Brasil. Encontros de Sociedades. Rio de Janeiro: Paz e Terra.

GODELIER, Maurice. 1981. « O Fundamento do pensamento selvagem”. In: E. A. Carvalho (org.). Godelier: Antropologia. São Paulo: Ática.

GODELIER, Maurice. 1996. L'Énigme du Don. Paris: Flammarion.

GODELIER, Maurice. 2010. Au Fondement des Sociétés Humaines. Ce que nous Apprend l'Anthropologie. Paris: Flammarion.

HILLMAN, James. 1997. O código do ser. Uma busca do caráter e da vocação pessoal. Rio de Janeiro: Editora Objetiva.

JUNQUEIRA, Carmen. 1967. Os Kamaiurá e o Parque Nacional do Xingu. Tese de Doutorado. São Carlos: Universidade de Campinas.

JUNQUEIRA, Carmen. 1978. Os Índios de Ipavu - Um estudo sobre a vida do grupo Kamaiurá. São Paulo: Ática.

JUNQUEIRA, Carmen e PAIVA, Eunice. 1985. O Estado Contra o Índio. São Paulo: Publicação do Programa de Estudos Pós-Graduados em Ciências Sociais - PUC.

JUNQUEIRA, Carmen. 1996. “Maíra”. In: D. Ribeiro (Org.). Maíra. Rio de Janeiro: Record.

JUNQUEIRA, Carmen. 2002. Sexo e desigualdade entre os Kamaiurá e os Cinta Larga. São Paulo: Olho d'água.

JUNQUEIRA, Carmen. 2004. "Pajés e feiticeiros”. Revista Estudos Avançados. 18 (52): 289-302.

JUNQUEIRA, Carmen. 2008. Antropologia Indigena (Uma nova Introdução). São Paulo: EDUC.

JUNQUEIRA, Carmen. 2010a. "Disputa política na sociedade Kamaiurá". Revista Brasileira de Linguistica Antropológica. 1:215-233.

JUNQUEIRA, Carmen. 2010b. “Os diamantes do povo Cinta Larga”. In: D. Milan e O. Matos (Org.). Gemas da terra - imaginação estética e hospitalidade. São Paulo: SESC.

JUNQUEIRA, Carmen. 2015. "Linguagem dos Ritos", Revista Brasileira de Linguistica Antropológica.7: 21-33.

JUNQUEIRA, Carmen. 2017. O tempo e o imaginário - O pajé e a antropóloga, 50 anos de diálogo.

Manaus: EDUA. Disponível em: www.pucsp.br/sites/default/files/.../livro_carmen_junqueira_1.pdf 
JUNQUEIRA, Carmen e VITTI, Taciana. 2009. “O kwarýp Kamaiurá na aldeia de Ipavu”. Revista Estudos Avançados. 23: 133-148.

LEITE, Marcelo. 2017. “As Montanhas Sagradas dos Yanomanis”. Ilustríssima. Folha de São Paulo. LEVI STRAUSS, Claude. 1971. Mythologiques - L’homme nu, tome 4. Paris: Plon.

LÉVI-STRAUSS, Claude. 1976a. As Estruturas Elementares do Parentesco. Petrópolis: Vozes. LÉVI-STRAUSS, Claude. 1976b. O Pensamento Selvagem. São Paulo: Companhia Editora Nacional.

MAUSS, Marcel. 1974. "Ensaio sobre a dádiva. Forma e Razão da troca nas sociedades arcaicas”. In: Sociologia e Antropologia. São Paulo: EPU.

MEILLASSOUX, Claude. 1977. Mulheres, Celeiros \& Capitais. Porto: Editora Afrontamento.

RAMOS, Alcida Rita. 2010. "Revisitando a Etnologia Brasileira”. In: C. B, Martins (coord.) e L.F.D, Duarte (org.). Horizontes das Ciências Sociais no Brasil/ Antropologia. São Paulo: AMPOCANPOCS.

RAMOS, Diego Faust. 2010. O tempo Kamayurá. Dissertação de mestrado. Florianópolis: UFSC.

RIBEIRO, Darcy. 1968. O processo civilizatório: etapas da evolução sociocultural. São Paulo: Civilização Brasileira.

RIBEIRO, Darcy. 1995. O Povo Brasileiro. São Paulo: Companhia das Letras.

ROUSSEAU, Jean-Jacques. 1959. Les Confissions - Autres textes autobiographiques. OEuvres Complètes, tome I. Bibliothèque de la Pléiade. Paris: Gallimard.

SAHLINS, Marshall. 1965. «On the sociology of Primitive Exchange ». In: M. Bantonn (ed.). The Relevance of models for Social Antropology. Monographs I. London / New York: Tavistock Publications.

TURNER, Terence. 2009. « The crisis of late structuralism. Perspectivism and animism: rethinking culture, nature, spirit, and bodiliness ». Tipiti 7 (1): 1- 42 .

SZTUTMAN, Renato. "A inconstância da alma selvagem e outros ensaios de antropologia de Eduardo Viveiros de Castro". Revista Sexta Feira. www.antropologia.com.br/comu/colab/c13-release_vcastro.pdf.

VIVEIROS DE CASTRO, Eduardo. 2002. Inconstância da Alma Selvagem. São Paulo: Cosac \& Naify. 


\section{UMA REVISÃo CRÍTICA DA ANTROPOLOGIA DE CARMEN JUNQUEIRA}

Resumo: O artigo faz uma revisão crítica da antropologia produzida pela antropóloga Carmen Junqueira, junto ao povo Kamaiurá, do alto Xingu, ao longo de cinquenta anos de pesquisa. O texto faz ainda uma tentativa de relacionar a perspectiva histórica adotada pela antropologia de Carmen Junqueira e a perspectiva que dá conta da composição do universo, em termos de pluralidade de mundos, destacando os modelos desenvolvidos por Philippe Descola (2005; 2017) e Viveiros de Castro (2002) e a sociologia política de Luc Boltanski e Laurent Thévenot (1991). O interesse deste exercício é apontar as potencialidades abertas pelo trabalho etnológico de Junqueira para uma interlocução com abordagens contemporânea das ciências sociais. A cosmologia indígena, o imaginário e o simbólico como constituição de realidades sociais, a circulação de bens e prestígio em um contexto político interétnico, são alguns dos temas que abrem uma série de reflexões e comparações entre estas diferentes perspectivas.

Palavras chaves: Antropologia indígena, relações de poder, mulheres indígenas, ritos e mitos, natureza e cultura

\section{A CRITICAL REVIEW OF THE ANTHROPOLOGY OF CARMEN JUNQUEIRA}

Abstract: This article reviews the research produced by the anthropologist Carmen Junqueira, during the over fifty years she spent studying the Kamaiurá people of the upper Xingu. The article attempts to relate the historical perspective adopted by Carmen Junqueira in her anthropological work and the perspective that gives an account of the composition of the universe in terms of the plurality of worlds, highlighting the models developed by Philippe Descola $(2005$; 2017) and Viveiros de Castro (2002) and the political sociology of Luc Boltanski and Laurent Thévenot (1991). The interest of this exercise is to point out the potentialities opened by the Junqueira's ethnological work for an interlocution with contemporary approaches of the social sciences. The indigenous cosmology, the imaginary and the symbolic as constitution of social realities, the circulation of goods and prestige in an interethnic political context, are some of the themes that open up a series of reflections and comparisons between these different perspectives.

Keywords: Indigenous anthropology, power relations, indigenous women, rituals and myths, nature and culture.

RECEBIDO: $10 / 01 / 2018$

APROVADO: $20 / 04 / 2018$ 
116 CAMPOS V.18(1-2), 2017 